\title{
Human Organoids for Predictive Toxicology Research and Drug Development
}

\author{
Toshikatsu Matsui and Tadahiro Shinozawa* \\ Drug Safety Research and Evaluation, Research, Takeda Pharmaceutical Company Limited, Fujisawa, Japan
}

Organoids are three-dimensional structures fabricated in vitro from pluripotent stem cells or adult tissue stem cells via a process of self-organization that results in the formation of organ-specific cell types. Human organoids are expected to mimic complex microenvironments and many of the in vivo physiological functions of relevant tissues, thus filling the translational gap between animals and humans and increasing our understanding of the mechanisms underlying disease and developmental processes. In the last decade, organoid research has attracted increasing attention in areas such as disease modeling, drug development, regenerative medicine, toxicology research, and personalized medicine. In particular, in the field of toxicology, where there are various traditional models, human organoids are expected to blaze a new path in future research

OPEN ACCESS

Edited by:

Toshio Imai,

National Cancer Centre, Japan

Reviewed by:

Ola Hermanson,

Karolinska Institutet (KI), Sweden

Katsuhiro Miyajima,

Tokyo University of Agriculture, Japan

*Correspondence:

Tadahiro Shinozawa

tadahiro.shinozawa@takeda.com

Specialty section:

This article was submitted to

Toxicogenomics,

a section of the journal

Frontiers in Genetics

Received: 31 August 2021

Accepted: 11 October 2021

Published: 01 November 2021

Citation:

Matsui T and Shinozawa T (2021)

Human Organoids for Predictive

Toxicology Research and

Drug Development.

Front. Genet. 12:767621.

doi: 10.3389/fgene.2021.767621 by overcoming the current limitations, such as those related to differences in drug responses among species. Here, we discuss the potential usefulness, limitations, and future prospects of human liver, heart, kidney, gut, and brain organoids from the viewpoints of predictive toxicology research and drug development, providing cutting edge information on their fabrication methods and functional characteristics.

\footnotetext{
Keywords: organoid research, liver organoid, cardiac organoid, kidney organoid, intestinal organoid, brain organoid, predictive toxicology, drug development
}

\section{INTRODUCTION}

Drug-induced adverse drug reactions are one of the leading causes for the discontinuation of drug development projects and the withdrawal of drugs from the market (Cook et al., 2014). It is, thus, essential to minimize adverse reactions to improve patient safety. For pharmaceutical companies, the decision to discontinue drug development due to adverse reactions at an early stage leads to a reduction in development costs and human resources. Therefore, studies focused on accurately predicting potential drug-induced adverse effects in humans in the early stages of drug development are important (Fitzpatrick, 2020). Toxicity studies have previously relied on animals, but species differences in anatomy, function, and morphology in various tissues have hampered the accurate understanding of the mechanisms of toxicity and the acquisition of accurate predictions regarding

\footnotetext{
Abbreviations: ASCs, adult tissue-resident stem cells; ADME, absorption, distribution, metabolism, and excretion; CMs, cardiomyocytes; DIKI, drug-induced kidney injury; ECTs, engineered cardiac tissues; ETV2, ETS mutant 2; hADSCs, human adipose-derived stem cells; hCFs, human cardiac fibroblasts; hCMECs, human cardiac microvascular endothelial cells; hCO, human cortical organoids; HUVECs, human umbilical vein endothelial cells; hvCOC, human ventricle-like cardiac organoid chamber; iPSCs, induced pluripotent stem cells; MEA, multi-electrode arrays; PL, phospholipidosis; PSCs, pluripotent stem cells; PHH, primary human hepatocytes; PTECs, proximal tubule epithelial cells.
} 
toxicity in humans (Van Norman, 2019; 2020). Additionally, animal studies are expensive and time-consuming, which can limit the number of substances tested. Therefore, in vitro assays using human cells are required to overcome these problems and to align with the concept of the 3 Rs (replacement, reduction, and refinement).

Organoids are miniature organs prepared from adult tissueresident stem cells (ASCs) or pluripotent stem cells (PSCs) in vitro (Bartfeld and Clevers, 2017). They are formed as three-dimensional (3D) tissue-like structures through the selforganization, self-renewal, and differentiation capacity of the stem cells (Fatehullah et al., 2016). Compared to the conventional two-dimensional (2D) cultured cells or spheroids, organoids are anatomically and functionally close to the organs in the living body (Kim et al., 2020), and they can be constructed from both normal and diseased tissues. Thus, various research applications using human organoids are expected, not only for basic research such as embryology, physiology, and evolution but also to help understand disease conditions and for drug discovery research, such as drug efficacy and toxicity (Kim et al., 2020). Additionally, organoids hold great promise for regenerative medicine (Rodrigues and Banales, 2021).

In this review, we described drug-induced organ toxicities in five areas or organs (liver, heart, kidneys, gastrointestinal tract, and brain); additionally, the in vitro predictive assays using human corresponding cells that have been developed so far are also mentioned. Furthermore, we present state-of-the-art examples of toxicity studies using $3 \mathrm{D}$ human organoids produced from human stem cells, which have received growing attention in recent years, and expand on their limitations and prospects. The cell sources, fabrication methods, and characteristics of these $3 \mathrm{D}$ organoids are described in detail in each subsequent section and summarized in Table 1 at the end of this article. The test drugs used and the toxic endpoints measured in these organoid studies are also included in the Table 1.

\section{LIVER ORGANOIDS AND THE PREDICTION OF HEPATOTOXICITY}

\section{Overview}

Drug-induced hepatotoxicity is a serious problem (Hoofnagle and Bjornsson, 2019). It reduces the probability of clinical success and is a major reason for drug withdrawal from the market (Cook et al., 2014). Additionally, it causes acute liver injury (Reuben et al., 2010) and ranks high in the list of drug-induced adverse reactions that occur in the clinical setting. Although animal studies have been conducted to predict the risk of druginduced hepatotoxicity, it has been reported that, owing to species differences, only $40-50 \%$ of clinical hepatotoxicity can be predicted (Olson et al., 2000). There has, consequently, been a focus on the development of highly predictive assays for druginduced hepatotoxicity and various in vitro assays using human hepatic cells. To date, 2D cultured HepG2 (Tolosa et al., 2012), HepaRG, primary human hepatocytes (PHH), and PSC-derived hepatocyte-like cells ( $\mathrm{Lu}$ et al., 2015b) have been utilized to evaluate toxicity. However, HepG2 is a human hepatoma cell line that does not express cytochrome P450 enzymes (Guo et al., 2011). HepaRG is another differentiated hepatic cell line, but it expresses various CYPs, as opposed to HepG2, and has thus been used for high-throughput toxicity screening (Saito et al., 2016). However, HepaRG do not produce detectable levels of urea (Lubberstedt et al., 2011). PHH is considered the gold standard hepatic cell model (Gomez-Lechon et al., 2014); however, it rapidly undergoes dedifferentiation upon 2D culture (Elaut et al., 2006), loses metabolic activity, and does not proliferate in vitro, making it difficult to obtain a large amount of $\mathrm{PHH}$ for large-scale screening. Inter-donor functional variability also exists in $\mathrm{PHH}$ (den Braver-Sewradj et al., 2016). Human PSCs have attracted increasing attention for their ability to proliferate indefinitely and differentiate into hepatocyte-like cells in vitro. However, hepatocyte-like cells derived from human PSCs have an immature phenotype (Schwartz et al., 2014; Baxter et al., 2015). Furthermore, the liver is composed of several cell types, including cholangiocytes, stellate cells, Kupffer cells, and liver sinusoidal endothelial cells, in addition to hepatocytes. Each of these cell types possesses unique functions that cooperatively regulate the physiological hepatic functions (Trefts et al., 2017). Based on the facts mentioned above, it is possible that the current $2 \mathrm{D}$ cultured hepatocytes including the gold standard hepatic model $\mathrm{PHH}$ do not fully recapitulate physiological liver function, and the role of non-hepatocytes should be considered in future disease modeling, drug screening, and toxicity assessments.

To overcome these limitations, scientists have struggled to create a more physiologically relevant in vitro hepatic model. In 2015, Huch et al. succeeded in producing functional 3D hepatic organoids that were differentiated from ductal cells that had been extracted from cell suspensions obtained through the collagenase-mediated digestion of human liver biopsy tissues, and showed that the expanded cells that had differentiated from the adult bile duct-derived cells had preserved their genetic integrity after being cultured for a period of months (Huch et al., 2015). Takebe et al. first reported the creation of hepatic organoids by co-culturing human iPSCs-derived hepatic endoderm cells, human umbilical vein endothelial cells (HUVECs), and mesenchymal cells (Takebe et al., 2013). The resulting liver bud organoids developed into hepatic tissues, showing mature hepatic features upon transplantation into mice. They also established a method to produce liver organoids from endodermal, endothelial, and mesenchymal progenitor populations specified entirely from human iPSCs (Takebe et al., 2017). These liver organoids that were differentiated from either human ASCs or PSCs are expected to fill the gap between 2D human cell cultures and animal models because they are more physiologically relevant to adult liver tissue and can thus be utilized for liver disease modeling, regenerative medicine, and drug screening. Indeed, there have been several studies using human liver organoids for toxicological evaluations. Sgodda et al. developed a scalable 3D suspension culture system in which human ESCs-derived hepatic cells could be maintained for up to 3 weeks (Sgodda et al., 2017). They differentiated human ESCs into hepatic progenitors by modulating the WNT signaling 
pathway and transferred them to a $3 \mathrm{D}$ culture system to enhance organoid formation. The fabricated ESC-derived 3D hepatic organoids were more sensitive to acetaminophen-induced toxicity than 2D cultured ESC-derived hepatic cells. Forsythe et al. produced human liver organoids by embedding a cell suspension composed of $80 \%$ primary human hepatocytes, $10 \%$ hepatic stellate cells, and $10 \%$ Kupffer cells into Matrigel, and seeded them into non-adherent, round-bottom, 96-well plates to form aggregates and produce spherical organoids (Forsythe et al., 2018). They screened four environmental heavy metals using the fabricated $3 \mathrm{D}$ hepatic organoids and examined changes in the ATP content as a toxicity readout. All the tested substances showed dose-dependent toxicity and proposed the utility of $3 \mathrm{D}$ organoids for toxicity screening applications. Lee et al. created 3D hepatic organoids to predict drug-induced phospholipidosis (PL). They isolated duct cells from human liver tissue and embedded them in Matrigel, followed by the addition of differentiation factors to create the organoids (Lee et al., 2020). They, then, compared the effects of three marketed drugs known to cause PL in both $3 \mathrm{D}$ hepatic organoids and conventional 2D cultured HepG2 cells, by analyzing the differences in function, morphology, and gene expression between the two assay systems. They found that the $3 \mathrm{D}$ cultured hepatic organoids were more sensitive to drug-induced PL. The above-mentioned reports examined only a few test substances for toxicity evaluation using 3D organoids. However, Shinozawa et al. reported the development and validation of high-throughput toxicity screening using hepatic 3D organoids. They fabricated self-organized human liver organoids that had human hepatocyte-like properties, including bile transport function, by embedding foregut cells differentiated from human iPSCs into Matrigel (Shinozawa et al., 2021). After confirming organoid formation, they added maturation factors and replated the embedded organoids in floating cultures and seeded them onto 384-well plates for high-throughput live imaging. Using this methodology, they evaluated 238 pharmaceuticals, including 32 negative controls and 206 reported DILI compounds, using bile acid transport activity and cell viability as readouts. The results revealed high predictivity, with $88.7 \%$ sensitivity and $88.9 \%$ specificity. They also demonstrated that bosentan-induced cholestasis is specific to CYP2C9 ${ }^{\star} 2 \mathrm{HLO}$, suggesting that different susceptibilities based on the polymorphism can be observed using human liver organoids.

\section{Limitations and Future Perspectives}

Studies on the prediction of drug-induced hepatotoxicity using human 3D liver organoids are still limited, but they are expected to increase in the future, as they are attracting increasing attention. From a practical point of view, it is important to compare the predictability of drug-induced hepatotoxicity in conventional 2D cultures and complex 3D organoid culture systems using a wide array of drugs. Such large-scale validation studies will help us gain a better understanding of drugs/MOA that are detectable or not detectable, depending on the different hepatic models. Another point to consider is the immaturity of $3 \mathrm{D}$ liver organoids, as it has been reported that
PSC-derived hepatocytes express immature or fetal markers (Harrison et al., 2021) and do not have all the functions of mature hepatocytes. Various approaches have been proposed to address this issue, including the overexpression of transcription factors or miRNAs and the addition of growth factors or small molecules to promote the differentiation and maturation of hepatocytes (Chen et al., 2018). Assay systems using human hepatocytes, which more closely resemble the functions of adult liver tissue, could help predict potential drug-induced hepatotoxicity more accurately in humans. Robust assay reproducibility among laboratories is also necessary for the adoption of organoid-based toxicity screening during early drug development.

\section{CARDIAC ORGANOIDS AND THE PREDICTION OF CARDIOTOXICITY}

\section{Overview}

Drug-induced cardiotoxicity is the leading cause of drug attrition during the development process (Cook et al., 2014). Various categories of drugs are known to cause prolonged QT and torsades de pointes (TdP), a life-threatening ventricular arrhythmia (Roden, 2016). In addition, many cancer drugs have been reported to cause reduction in the left ventricular ejection fraction (LVEF), and their long-term use is associated with an increased risk of developing chronic heart failure (Kerkela et al., 2006; Chu et al., 2007; McGowan et al., 2017). These factors contribute to their discontinuation during drug development (Ferri et al., 2013) and are clinically problematic (Hall et al., 2013; Roden, 2016). Both rodents and larger animals are used to monitor cardiac function via ECG or echocardiography to determine whether a candidate drug causes alterations in cardiac function during the later phases of development. However, because of the differences in cardiac function among species, the labor-intensive and time-consuming nature of animal experiments, and due to considerations for the $3 \mathrm{Rs}$, there is a growing demand to develop an assay system that can predict drug-induced cardiotoxicity in humans with a high accuracy during the early stages of drug development. Cell-based functional and structural assays have been used as in vitro prediction tools for drug-induced cardiotoxicity. In particular, the binding assay in HEK293 cells expressing human ether-agogo related gene (HERG) $\mathrm{K}+$ channels has classically been utilized to identify compounds that could possibly prolong QT (Bowlby et al., 2008). Recently, with the advent of stem cellderived cardiomyocytes (CMs), cardiac functional assessments, such as multi-electrode arrays (MEA) (Ando et al., 2017; Yamazaki et al., 2018), patch clamps (Scheel et al., 2014), and calcium transient assays (Lu et al., 2015a; Pfeiffer et al., 2016), using human PSC-derived CMs have been utilized to predict drug-induced QT prolongation and fatal arrhythmia. Cardiac contractile function has also been assessed using non-invasive motion vector analysis or impedance-based measurements to predict drug-induced alterations in contractility (Hayakawa et al., 2012; Lamore et al., 2013; Mills et al., 2017; Poulton, 2017; Okai et al., 2020). Furthermore, HCA-based structural 
cardiotoxicity assays (Grimm et al., 2015; Sharma et al., 2017; Matsui et al., 2019), using cytotoxicity, sarcomere morphology, mitochondrial integrity, or reactive oxygen species (ROS) formation as readouts, have also been developed. These functional and structural assays have been exclusively developed using 2D monocultured stem cell-derived CMs. However, CMs occupy less than $50 \%$ of the whole heart (Bergmann et al., 2015) and, thus, their role cannot be neglected; additionally, the effects of drugs on noncardiomyocytes and the subsequent indirect effects of noncardiomyocytes on cardiomyocytes via cell-cell interactions cannot be assessed using the methods described.

Therefore, to further recapitulate cardiac physiological characteristics in vitro, various studies have been conducted to create 3D human cardiac organoids/microtissues using a cell suspension composed of stem cell-derived $\mathrm{CMs}$ ) and various non-CMs [such as primary human cardiac fibroblasts (hCFs), human umbilical vein endothelial cells (HUVECs), primary human cardiac microvascular endothelial cells (hCMECs), and human adipose-derived stem cells (hADSCs)] that are seeded in hydrogel molds with ECM to assemble cardiac organoids (Patel et al., 2017; Richards et al., 2017; Patel and Birla, 2018; Mills et al., 2019; Schulze et al., 2019; Richards et al., 2020). Cardiac organoids/microtissues fabricated using these methods are expected to better reflect human heart physiology and be useful in modeling human cardiac disease, drug screening, and the development of regenerative medicines [44]. Unique 3D engineered cardiac tissues (ECTs) were developed using human hiPSC-CMs and fibroblasts in the scalable tissuecultivation platform "BiowireTM II" that allows noninvasive recording of cardiac contractions, action potentials, and conduction velocities (Zhao et al., 2019). The research group embedded suspensions of both iPSC-CMs and cardiac fibroblasts in a hydrogel, then seeded them in a BiowireTM II platform microwell and conducted 10-weeks electrical field stimulations to promote maturation. Using the fabricated ECTs, they assessed the effects of several different positive and negative inotropes on cardiac contractility and obtained good concordance, suggesting that such assay platforms could be utilized early in the drug discovery process (Feric et al., 2019; Qu et al., 2020). A similar approach has also been developed by another group (Tiburcy et al., 2017; Cyganek et al., 2018). Interestingly, Li et al., for the first time, developed a novel in vitro system that allows for the direct measurement of cardiac performance as a pump by fabricating a 3D electromechanically coupled human ventriclelike cardiac organoid chamber (hvCOC) (Li et al., 2018; Keung et al., 2019). Using the hvCOC, they were able to measure detailed parameters related to cardiac contractility, such as stroke volume, $\mathrm{EF}$, cardiac output, and pressure volume loop. Using the fabricated hvCOC and 25 cardioactive compounds covering various drug classes, they assessed the predictivity of the assay and achieved a high prediction accuracy of more than $80-100 \%$. Furthermore, Archer et al. created 3D cardiac microtissues using cell suspensions composed of human iPSC-CMs, hCMECs, and hCFs, and seeded them onto 384-well ultra-low attachment spheroid microplates (Archer et al., 2018). Using the fabricated cardiac microtissues and HCA-based simultaneous detection of multiple parameters related to cellular damage (ATP depletion, endoplasmic reticulum (ER) integrity, and mitochondrial membrane potential), they assessed 15 FDAapproved structural cardiotoxins and 14 FDA-approved nonstructural cardiotoxins. The results showed that structural cardiotoxicity could be detected at therapeutically relevant concentrations and conferred high prediction accuracy when compared to 2D-cultured human iPSCs. Notably, in vitro modeling of post-myocardial infarction (MI) was performed by Richards et al. using cardiac organoids (Richards et al., 2020). They prepared cell suspensions containing 50\% human iPSC-CMs and 50\% non-myocytes, including hCFs, HUVECs, and hADSCs, seeded them into agarose hydrogel molds, and submerged them with culture medium for 4 days to create selfassembled organoids. Then, the organoids were incubated under hypoxic $\left(10 \% \mathrm{O}_{2}\right)$ conditions and noradrenaline was added for 10 days to mimic the in vivo MI conditions in which there is compensatory activation of the sympathetic nerves to restore decreased cardiac output. Both functional and structural assessments as well as global gene expression analyses have demonstrated that the fabricated organoids can mimic many of the pathological hallmarks of MI (pathological metabolic shifts, increased fibrosis, and abnormal calcium handling). Enhanced doxorubicin-cardiotoxicity in the MI organoid model has also been reported. These findings suggest that human organoids modeling diseases with non-genetic pathologic factors are useful for drug screening and increase the possibility of personalized models for safety assessments.

\section{Limitations and Future Perspectives}

3D cardiac organoids/microtissues generated from human PSCs do not yet contain all the cells present in the adult heart, such as immune cells, which play an important role in providing the protective inflammatory responses required for host defenses against infection (Lafuse et al., 2020); additionally, they are also reported to contribute to the pathogenesis of $\mathrm{HF}$ (Carrillo-Salinas et al., 2019). Thus, a novel assay system, such as the co-culture of PSC-CMs and immune cells, may help us to gain a deeper understanding of the crosstalk between CMs and immune cells. Furthermore, efforts to develop such assay systems may help reveal the mechanisms underlying immune checkpoint inhibitor-related cardiotoxicity (Michel et al., 2019; Behravesh et al., 2020; Xu et al., 2021) and to mimic such adverse effects in vitro. Another limitation of the 3D cardiac organoids/ microtissues is that the degree of maturation for the fabricated organoids is not yet sufficient, when compared to adult cardiac tissues, in terms of morphology, function, and gene expression, and this prevents accurate predictions of drug-induced cardiotoxicity. To overcome this limitation, various strategies have been developed to enhance the maturation of PSC-derived $\mathrm{CMs}$, such as the addition of hormones, changing cellular energy sources or substrate stiffness, conducting continuous electrical stimulations, and utilizing 3D culture systems (Ahmed et al., 2020). Such efforts toward maturation will contribute to a higher accuracy in predicting drug-induced cardiotoxicity in humans. Furthermore, from a practical perspective, each in vitro cardiotoxic assay should be used at different stages depending 
on the purpose during development (for early-stage screening or mechanistic toxicity study). A robust and standardized assay protocol is also required to minimize interfacility differences, especially when sophisticated in vitro assays are used for the mechanistic understanding of drug-induced cardiotoxicity.

\section{KIDNEY ORGANOIDS AND THE PREDICTION OF KIDNEY TOXICITY}

\section{Overview}

Drug-induced kidney injury (DIKI) is a serious problem worldwide (Pavkovic and Vaidya, 2016) and is responsible for $19 \%$ of acute renal failure cases (Cook et al., 2014). DIKI is also one of the causes of drug attrition during drug development (Cook et al., 2014). A wide variety of drugs, including cisplatin, NSAIDs, antibiotics, and contrast agents, are known to cause injury in various regions of the kidney (Soo et al., 2018). Therefore, in vitro assays that can predict drug-induced kidney injury during the early stages of drug development are urgently required. An ideal renal cell culture model would be one in which cells display the expression of functional drug transporters, the maintenance of metabolic functions, and the expression of biomarkers observed in clinical settings (Zhang and Parikh, 2019). These factors are expected to increase the value of DIKI predictions. However, in the absence of such ideal and appropriate renal cells, no standard or established in vitro assays have yet been used to predict DIKI. To date, 2D cultured human renal proximal tubule epithelial cells (PTECs) have been commonly used for the prediction of DIKI (Adler et al., 2016). This is because the proximal tubules are the primary target for DIKI, as they are most frequently exposed to drugs and have high metabolic activities, and imbalances in uptake and efflux activities cause intracellular accumulation of drugs and subsequent toxic injury. $\mathrm{Su}$ et al. evaluated a reference set of 44 compounds, including nephrotoxicants and nonnephrotoxicants, using 2D-cultured PTECs and highthroughput imaging analysis (Adler et al., 2016). With the use of machine learning techniques, the assay exhibited good predictability with an accuracy of more than $80 \%$. PTEC has limited proliferative capacity and inter-donor variability in toxic readouts; thus, immortalized proximal tubule epithelial cell lines are also used to overcome these limitations. Another group also reported a similar HCA-based approach using conditionally immortalized PT epithelial cells that were stably expressing OAT1 for a panel of 62 drugs and they showed a good prediction accuracy with $75 \%$ sensitivity and $100 \%$ specificity (Sjogren et al., 2018). However, these 2D monoculture assays using PTEC or immortalized cell lines suffer from dedifferentiation, decreased expression of transporters, and decreased metabolic function. In addition, the kidney is a complex, multicellular organ composed of over 20 different cell types, and the parts of the nephron (glomeruli, proximal tubule, distal tubule, and collecting duct) that are affected varies with different nephrotoxic compounds, and there is a marked diversity in the mechanisms by which compounds affect renal function (Soo et al., 2018).
To address this issue, the creation of kidney organoids or kidney tissue models has become a focus to help mimic kidney physiology. In 2013, Desrochers et al. first reported the potential utility of a $3 \mathrm{D}$ human renal tissue system created using the transwell-based 3D cultures of immortalized human renal cortical NKi-2 cells embedded in an ECM solution (DesRochers et al., 2013). They evaluated the acute and chronic effects of representative nephrotoxic drugs (cisplatin, gentamicin, and doxorubicin) using 2D monocultured NKi-2 and $3 \mathrm{D}$ kidney tissue models and showed that 3D tissues were more sensitive to drug-induced toxicity. In 2015, three different groups reported fabrication methods for 3D kidney organoids from human stem cells. Freedman et al. reported the fabrication of segmented, nephron-like kidney organoids containing proximal tubule, podocyte and endothelial cell populations by adding a GSK3b inhibitor to cavitated spheroids formed by 3D cultured human stem cells; additionally, they also examined the reactivity of cisplatin and gentamicin in tubular organoids and confirmed elevated levels of Kim-1 (Freedman et al., 2015). Furthermore, in a separate study, they also reported a fully automated and highthroughput screening (HTS)-enabled platform for the production of kidney organoids from human PSCs, their analysis for toxicity assessment and improvement of mechanistic understanding of polycystic kidney disease (Czerniecki et al., 2018). Morizane et al. reported an efficient chemically defined protocol to differentiate human stem cells into nephron progenitor cells (NPCs) that can self-organize into nephron-like structures. They showed elevated expression of the KIM1 protein in the fabricated organoids upon simulation with gentamicin and cisplatin (Morizane et al., 2015). Takasato et al. differentiated human iPSCs not to nephron progenitor cells but to the intermediate mesoderm so that kidney organoids were made from two types of kidney progenitor cells. As a result, the kidney organoids contained not only tubules and glomeruli but also all cells necessary for kidney formation, including collecting ducts, blood vessels, and renal interstitial cells. The fabricated organoids showed an improved response to cisplatin, a nephrotoxicant that induces apoptosis in proximal tubular cells, suggesting that functional maturation of the nephrons within the fabricated organoids was provided (Takasato et al., 2015). To enable more accurate predictions of DIKI, King et al. created an in vitro model of the proximal tubule interstitial interface comprising renal fibroblasts, endothelial cells, and human PTECs using their proprietary 3D bioprinting platform (King et al., 2017). The fabricated 3D proximal tubule tissues demonstrated tight junction formation and expression of renal uptake and efflux transporters. Functional assessments revealed dose-dependent cisplatin toxicity, and that the OCT-2 inhibitor cimetidine rescued the injury and fibrotic response to TGFb (King et al., 2017). These 3D kidney organoids provide valuable information for the prediction of drug-induced kidney toxicity in humans.

\section{Limitations and Future Perspectives}

Although the number of kidney organoid studies has gradually increased in previous years, there have been no reports in which a large number of drugs were tested in 3D kidney organoids, as has been the case for 2D cultures (Adler et al., 2016; Sjogren et al., 
2018). To incorporate a predictive toxicity assay using kidney organoids for early screening during development, further comparative studies regarding the prediction accuracy between conventional 2D cultures and 3D organoid systems are required. In addition, in vitro toxicity assays have been performed exclusively based on the endpoints related to cell death, but incorporating appropriate readouts related to potential clinical DIKI biomarkers (KIM1, NGAL, and IGFB3) (Zhang and Parikh, 2019) may improve the prediction accuracy of DIKI in the $3 \mathrm{D}$ organoids. One drawback of 3D kidney organoids is the lack of blood flow; as the kidney is an organ that carries a large amount of blood, understanding its vascular structure is essential to accurately recapitulate kidney function. To avoid this problem, the usefulness of the Kidney-on-a-chip has been proposed (Wilmer et al., 2016). The ability to add shear stress has been shown to increase transporter expression (Vormann et al., 2018; Vriend et al., 2018). However, because these complex assay systems have poor throughput, it is necessary to determine the stage during drug development during which they be best utilized. It is also important to consider that various drugs are known to cause kidney injury in different parts of the nephron and the drugs currently used primarily for toxicity assessment using kidney organoids are those known to cause tubular toxicity rather than glomerular toxicity, such as gentamicin and cisplatin (Soo et al., 2018). Therefore, it is also essential to investigate if currently reported kidney organoids can also predict glomerular toxicity caused by drugs such as mitomycin $\mathrm{C}$ and nonsteroidal anti-inflammatory drugs (Markowitz et al., 2015) to further our understanding of the role of kidney organoids in predicting DIKI. Moreover, as there are no standard in vitro assays for DIKI, it is important to select an appropriate in vitro assay (highthroughput $2 \mathrm{D}$ monoculture or sophisticated $3 \mathrm{D}$ organoid) depending on the stage of drug development. Further efforts are needed to develop novel in vitro assay systems that better reflect the physiological functions of the human kidney.

\section{INTESTINAL ORGANOIDS AND THE PREDICTION OF GASTROINTESTINAL TOXICITY \\ Overview}

Drug-induced gastrointestinal toxicity (Pusztaszeri et al., 2007) is characterized by abdominal discomfort, abnormal peristalsis, anorexia, nausea, vomiting, abdominal pain, abnormal defecation (diarrhea/constipation), abnormal stools (mucous, tarry, or whitish), flatulence, hematemesis, and melena, and these symptoms are often present in combination. It is a common adverse event and a reason for discontinuation during drug development (Cook et al., 2014). A wide variety of drugs are known to affect different parts of the gastrointestinal (GI) tract (Pusztaszeri et al., 2007; Carr et al., 2017). To model the in vitro upper and lower gastrointestinal tracts, several human GI cells are available, including cancer cell lines, immortalized cells, and primary cells (Carr et al., 2017). However, primary cells cannot be cultured for a long period of time (Grossmann et al., 1998) and cancer cell lines and immortalized cells have low metabolic activity, lose physiological functions upon passage, different gene expression profiles when compared to those in vivo, and no original functional properties. As a result, in vitro drug-induced intestinal toxicity screening is rarely performed when compared to the organ toxicity described in the previous sections. As a cell-based assay, Caco-2 is regarded as a surrogate enterocyte and has been used primarily as the gold standard in a number of absorption, distribution, metabolism, and excretion (ADME) studies, including drug absorption and metabolism assessments (Wang et al., 2016); however, it has been used in relatively few studies for the prediction of clinically reported gastrointestinal toxicity. In conclusion, the prediction of gastrointestinal toxicity in humans is entirely dependent on animal studies. However, due to the differences in anatomy, biochemistry, and microorganisms in the gastrointestinal tissues of species, and to avoid the cost and efforts required for animal studies, a highly predictive in vitro assessment system is required.

Recently, fabrication methods for human intestinal organoids from intestinal epithelial stem cells (Sato et al., 2009) or PSCs (Spence et al., 2011; Takahashi et al., 2018) have been reported. In 2009, Sato et al. showed for the first time that intestinal epithelial tissue organoids could be constructed from Lgr5-positive stem cells isolated from crypt regions in the small intestine (Sato et al., 2009). They showed that crypt regions, including Lgr5-positive stem cells suspended in Matrigel, allowed for the ex vivo reconstruction of intestinal tissues that reflected intestinal epithelial cell proliferation and differentiation. They also demonstrated that the fabricated intestinal organoids could be cultured for more than 8 months. In 2011, Spence et al. differentiated human PSCs into endoderm with activin $\mathrm{A}$ and then differentiated them into CDX2-positive intestinal endoderm by adding FGF4 and Wnt3A, and transferred the floating spheroids formed into $3 \mathrm{D}$ cultures by embedding them in Matrigel to promote intestinal growth and differentiation (Spence et al., 2011). The fabricated 3D intestinal organoids were composed of a polarized columnar epithelium that was patterned into villus-like structures and crypt-like proliferative zones. Takahashi et al. established a sophisticated protocol to produce intestinal organoids from human intestinal crypts isolated from the healthy intestinal tissues of surgical specimens without the use of cytokines and Matrigel that are generally required for the culture of $3 \mathrm{D}$ organoids in order to provide a suitable method for high-throughput screening (Takahashi et al., 2018).

These intestinal organoids have attracted attention for a variety of applications, including disease modeling, intestinal-microbe interactions, pharmacology, and regenerative medicine, and they have shown promise for the prediction of toxicity (Bitar and Zakhem, 2016; Dedhia et al., 2016; Almeqdadi et al., 2019). From a toxicological point of view, Belair et al. generated 3D spherical ileal organoids from a Matrigel-embedded ileal crypt suspension extracted from commercially available human ileal tissues (Belair et al., 2020). Using ileal organoids, they evaluated 31 marketed drugs known to cause different degrees of clinical incidence of diarrhea with cell viability as a toxicity readout to predict drug-induced diarrhea; they obtained 90\% prediction accuracy (Belair et al., 2020). 
Peters et al. developed a non-spherical 3D Epi-Intestinal tissue model by culturing human fibroblasts and primary human small intestinal epithelial cells in collagen conditions in a Transwell format under an air-liquid interface (ALI) (Peters et al., 2019). Instead of focusing on endpoints related to cytotoxicity, such as ATP and LDH, which are often used in toxicity studies, they focused on the barrier function of the 3D microtissue model, as it is one of the GI-specific functional readouts. They performed a gut barrier function assay (TEER measurements) following treatment with 31 drugs used clinically as a reference set. Results revealed that the 3D EpiIntestinal tissue model showed higher predictability than the $2 \mathrm{D}$ cultured Caco-2 cells (Peters et al., 2019). These intestinal organoids/ models appear to be promising for the prediction of drug-induced intestinal toxicity in humans.

\section{Limitations and Future Perspectives}

3D intestinal organoids have attracted much attention in previous years, as they are expected to better reflect biological functions than conventional 2D cultures. However, currently reported 3D intestinal organoids do not contain cells associated with the vasculature, immune system, or enteric nervous system. In addition to diarrhea, drug-induced intestinal toxicity has a broad range of symptoms, and there are no models yet to predict nausea, vomiting, and constipation. Unlike gastrointestinal epithelial cells, complex co-cultures (involvement of the innate immune system and nervous system) may be required to further mimic gastrointestinal physiology. In addition, these 3D organoids are cultured under static conditions and do not experience fluid flows and cyclic mechanical deformations that are similar to physiological intestinal peristaltic movement. Thus, incorporating microphysiological systems, including organ-on-a-chip technology, into 3D intestinal organoids is expected to provide further potential value to recapitulate living human intestine (Bein et al., 2018). Indeed, Kasendra et al. developed a primary human small intestine-on-achip using biopsy-derived organoids (Kasendra et al., 2018). Global gene expression analysis revealed that organoids cultured on the intestine chip more closely mimicked the living duodenum than static duodenal organoids. It should also be taken into account that, in contrast to other organ disorders, there are relatively few validated biomarkers available for gastrointestinal diseases. As mentioned in the previous sections, the identification and validation of novel biomarkers related to gastrointestinal diseases and incorporating them as toxicity readouts will increase the predictive accuracy of in vitro assays using intestinal organoids. Furthermore, the fabrication of physiologically relevant intestinal organoids and cocultures with microbes (Puschhof et al., 2021) will provide a better understanding of host-microorganism interactions as well as drug-gut microbiota interactions that may be associated with altered therapeutic and toxic effects of various drugs (Weersma et al., 2020).

\section{BRAIN ORGANOIDS AND THE PREDICTION OF NEUROTOXICITY}

\section{Overview}

Drug-induced neurotoxicity includes both the structural neurotoxicity associated with tissue damage and functional neurotoxicity, which includes seizure/convulsions (Walker et al., 2018). These adverse effects are the major causes for discontinuation in candidate drug development. It was reported that the percentage of discontinued projects due to CNS adverse effects was $7 \%$ in the preclinical stage and $34 \%$ in the clinical trial stage (Cook et al., 2014). Therefore, as in the case of the liver and heart, there is a requirement for the early identification of drug candidates that have a risk of neurotoxicity. Since the discovery of human iPSCs and the development of methods for their differentiation into neuronal cells, in vitro predictive assays using iPSC-neurons have been conducted in previous years. Specifically, to predict druginduced structural and functional toxicity in humans, various readouts such as neuronal cell death, neurite outgrowth, calcium oscillation, and extracellular field potentials were measured in 2D cultured iPSC-derived neurons (Wilson et al., 2014; Bitar and Zakhem, 2016; Dedhia et al., 2016; Takahashi et al., 2018; Almeqdadi et al., 2019; Belair et al., 2020; Shirakawa and Suzuki, 2020).

In 2013, Lancaster et al. first reported the creation of 3D selforganising cerebral organoids from human stem cells (Lancaster et al., 2013). They generated neuroectoderm from human stem cell-induced embryoid bodies, embedded them in Matrigel, and transferred them to a spinning bioreactor to enhance nutrient absorption. After 20-30 days, 3D self-organizing cerebral organoids that exhibited various cell lineages, including the forebrain, midbrain, hindbrain, retina, and choroid plexus, were obtained. In addition, by altering the concentrations and compositions of the morphogen (external patterning factors) during culture, the stem cells could differentiate into brain region-specific organoids, such as the cerebral cortex (Pasca et al., 2015), hippocampus (Sakaguchi et al., 2015), midbrain (Qian et al., 2016), and cerebellum (Muguruma et al., 2015). Among them, cerebral brain organoids have attracted particular attention. Human brain organoids are expected to provide valuable information to improve our understanding of the mechanisms of neurodevelopmental or neurodegenerative disorders and are useful tools for modeling and drug screening for such diseases (Chhibber et al., 2020). In addition, 3D brain organoids/models have been used in previous years to understand the effects of marketed drugs or environmental toxicants on human neuronal development. Focusing on the fact that human cerebral organoids from iPSCs are similar to fetal brains in terms of development and structure, Arzua et al. modeled alcohol-induced neurotoxicity using human 3D cerebral organoids to understand the mechanisms of fetal alcohol spectrum disorders (Arzua et al., 2020). They cultured human iPSCs in a chemically defined medium to aggregate them into embryoid bodies in ultra-low attachment plates and to initiate differentiation into neuroepithelial tissues, followed by the formation of cerebral organoids via Matrigel embedding. They, then, exposed the organoids to ethanol and found increased caspase three activity and functional (OCR reduction) and morphological alterations (less dense matrix and disrupted cristae) of the mitochondria in the $3 \mathrm{D}$ cerebral organoids. Specifically, neurons are more vulnerable to alcohol-induced apoptosis than astrocytes. Bu et al. also fabricated 3D cerebral 
TABLE 1 | Organoid-based toxicity assessment.

\begin{tabular}{|c|c|c|c|c|c|c|}
\hline $\begin{array}{l}\text { Organoid } \\
\text { type }\end{array}$ & $\begin{array}{l}\text { Organoid } \\
\text { sources }\end{array}$ & Fabrication methods & Characteristics & Test substances & Toxic endpoints & References \\
\hline \multirow[t]{3}{*}{$\begin{array}{l}\text { Liver } \\
\text { organoid }\end{array}$} & ESCs & $\begin{array}{l}\text { Differentiation of ESCs into } \\
\text { foregut endoderm } \\
\text { progenitor populations that } \\
\text { are further maturated into } \\
\text { hepatic progenitor cells by } \\
\text { the WNT signaling } \\
\text { pathway, then cultured } \\
\text { under 3D suspension } \\
\text { culture conditions }\end{array}$ & $\begin{array}{l}\text { By selecting the size of the } \\
\text { organoids, it is possible to } \\
\text { produce a more complex } \\
\text { structure, including } \\
\text { cholangiocytes and } \\
\text { stromal cells, in case of } \\
\text { large organoids }\end{array}$ & Acetaminophen & Viability (WST-1) & $\begin{array}{l}\text { Sgodda et al. } \\
\text { (2017) }\end{array}$ \\
\hline & $\begin{array}{l}\text { Primary human } \\
\text { hepatocytes, } \\
\text { hepatic stellate } \\
\text { cells, and Kupffer } \\
\text { cells }\end{array}$ & $\begin{array}{l}\text { Produced with a mixture of } \\
80 \% \text { hepatocytes, } 10 \% \\
\text { hepatic stellate cells, and } \\
10 \% \text { Kupffer cells and } \\
\text { seeded onto non- } \\
\text { adherent, round-bottomed } \\
\text { plates }\end{array}$ & $\begin{array}{l}\text { Composed of a } \\
\text { representative population } \\
\text { of cells in vivo, capable of } \\
\text { maintaining high viability } \\
\text { over a long period of time, } \\
\text { and is metabolically active, } \\
\text { able to respond to and } \\
\text { metabolize drugs } \\
\text { accurately }\end{array}$ & $\begin{array}{l}\text { Environmental toxins } \\
\text { (glyphosate, lead, } \\
\text { mercury, thallium) }\end{array}$ & $\begin{array}{l}\text { Viability (ATP and live cell } \\
\text { staining) }\end{array}$ & $\begin{array}{l}\text { Forsythe et al. } \\
\text { (2018) }\end{array}$ \\
\hline & Human liver tissue & $\begin{array}{l}\text { Isolation of duct cells from } \\
\text { human liver tissue by } \\
\text { chopping and enzyme } \\
\text { digestion, and embedding } \\
\text { of the isolated duct cells in } \\
\text { Matrigel followed by the }\end{array}$ & $\begin{array}{l}\text { Shows the characteristics } \\
\text { of hepatocytes rather than } \\
\text { HepG2 cells such as } \\
\text { positive nuclear staining of } \\
\text { HNF4A, clear positive } \\
\text { glycogen accumulation, }\end{array}$ & $\begin{array}{l}\text { PL-inducing drugs } \\
\text { (amikacin, amiodarone, } \\
\text { sertraline, } \\
\text { acetaminophen) }\end{array}$ & $\begin{array}{l}\text { Viability (ATP), } \\
\text { morphological changes, } \\
\text { albumin secretion, } \\
\text { expression of genes } \\
\text { related to } \\
\text { phospholipidosis }\end{array}$ & Lee et al. (2020) \\
\hline
\end{tabular}

iPSCs Differentiation of iPSCs into foregut, dissociation into single cells, and culture in a specialized medium to enhance organoid formation, followed by harvesting and resuspension in Matrigel on the Ultra-Low Attachment Multiwell Plate

Cardiac iPSCs and organoid fibroblasts

ESCs and fibroblasts
Cell suspension consisted of $90 \%$ iPSC-derived CMs $10 \%$ cardiac fibroblasts were suspended in a hydrogel, seeded in a specialized culture platform microwell (Biowire $\left.^{\mathrm{TM}} \mathrm{II}\right)$, and subjected to a 10-weeks electrical field stimulation to promote maturation

Cell suspension consisted of $90 \%$ ESC-derived CMs, and $10 \%$ dermal fibroblasts were resuspended in aqueous scaffold materials (Matrigel and collagen I solution) in a dedicated bioreactor, followed by gelation and self-assembly during incubation to fabricate a miniature cardiac organoid that mimics a human ventricle and a more stable albumin secretion

Exhibits properties that include bile transport

functions, allows

assessment of

susceptibility based on polymorphism at organoid resolution, and is amenable to high-throughput toxicity screening

Shows positive force frequency and post-rest potentiation and improved sarcomeric organization and is enriched for gene expression patterns of the corresponding adult human heart cardiac regions, enables polygenic cardiac disease modeling

Shows organized

sarcomeres with myofibrillar microstructures, upregulation of key genes related to calciumhandling, ion channel, and cardiac-specific proteins and allows direct measurement of stroke volume, EF, cardiac output, pressure volume loop, and so on
238 marketed drugs including 206 DIL compounds and 32 nonDILI compounds

(Zhao et al.), 12

cardioactive drugs (Feric et al.) and 8 reported positive inotropes (Qu et al.)

6 cardioactive drugs ( $\mathrm{Li}$ et al.) and 25 cardioactive drugs (Keung et al.)

\section{Contractility, Calcium Z Zhao et a transients, and gene expression related to cardiotoxicity pathway (2019), Feric et al. (2019),Qu et al. (2020)}

Biliary excretion capacity, Shinozawa et al. cell viability (ATP), and (2021)
Li et al., 2018, Keung et al. 2019 
TABLE 1 | (Continued) Organoid-based toxicity assessment.

\begin{tabular}{|c|c|c|c|c|c|c|}
\hline $\begin{array}{l}\text { Organoid } \\
\text { type }\end{array}$ & $\begin{array}{l}\text { Organoid } \\
\text { sources }\end{array}$ & Fabrication methods & Characteristics & Test substances & Toxic endpoints & References \\
\hline \multirow[t]{2}{*}{$\begin{array}{l}\text { Cardiac } \\
\text { organoid }\end{array}$} & $\begin{array}{l}\text { iPSCs, hCMECs, } \\
\text { and hCFs }\end{array}$ & $\begin{array}{l}\text { Cell suspensions of iPSC- } \\
\text { derived CMs, hCMECs, } \\
\text { and hCFs in a ratio of 4:2:1 } \\
\text { were seeded in ultra-low } \\
\text { attachment spheroid } \\
\text { microplates }\end{array}$ & $\begin{array}{l}\text { Exhibits typical } \\
\text { morphological and cellular } \\
\text { compositional } \\
\text { characteristics similar to } \\
\text { those present in } \\
\text { myocardium and are } \\
\text { amenable to high- } \\
\text { throughput toxicity } \\
\text { screening }\end{array}$ & $\begin{array}{l}15 \text { FDA approved } \\
\text { structural cardiotoxins } \\
\text { and } 14 \text { FDA approved } \\
\text { nonstructural } \\
\text { cardiotoxins }\end{array}$ & $\begin{array}{l}\text { Viability (ATP), } \\
\text { endoplasmic reticulum } \\
\text { integrity, and } \\
\text { mitochondrial membrane } \\
\text { potential }\end{array}$ & $\begin{array}{l}\text { Archer et al. } \\
(2018)\end{array}$ \\
\hline & $\begin{array}{l}\text { iPSCs-CMs, hCFs, } \\
\text { HUVECs, and } \\
\text { hADSCs }\end{array}$ & $\begin{array}{l}\text { A cell suspension } \\
\text { composed of 50\% iPSC- } \\
\text { derived CMs and 50\% } \\
\text { non-myocytes (at a 4:2:1 } \\
\text { ratio of FBs: HUVECs: } \\
\text { hADSCs) was seeded into } \\
\text { agarose hydrogel molds } \\
\text { and submerged with } \\
\text { culture medium, followed } \\
\text { by incubation under } \\
\text { hypoxic conditions and } \\
\text { treatment with } \\
\text { noradrenaline }\end{array}$ & $\begin{array}{l}\text { Mimics the characteristics } \\
\text { of myocardial infarction, } \\
\text { including pathological } \\
\text { metabolic changes, fibrosis } \\
\text { and altered calcium } \\
\text { handling, at transcriptomic, } \\
\text { structural, and functional } \\
\text { levels }\end{array}$ & doxorubicin & $\begin{array}{l}\text { Contractility and } \\
\text { apoptosis (TUNEL } \\
\text { staining) }\end{array}$ & $\begin{array}{l}\text { Richards et al. } \\
(2020)\end{array}$ \\
\hline \multirow[t]{4}{*}{$\begin{array}{l}\text { Kidney } \\
\text { organoid }\end{array}$} & ESCs and iPSCs & $\begin{array}{l}\text { Differentiation of 3D } \\
\text { cultured PSC-derived } \\
\text { cavitated spheroids into } \\
\text { segmented, nephron-like } \\
\text { kidney organoids by } \\
\text { GSK3b inhibition to result } \\
\text { in cell population with } \\
\text { proximal tubular, } \\
\text { podocyte, and endothelial } \\
\text { characteristics }\end{array}$ & $\begin{array}{l}\text { 3D culture system that } \\
\text { reconstitutes functional, } \\
\text { structured epithelia } \\
\text { modelling the epiblast, } \\
\text { kidney tubular cells, and } \\
\text { podocyte-like cells }\end{array}$ & cisplatin and gentamicin & $\begin{array}{l}\text { Expression of kidney } \\
\text { injury biomarker (Kim-1) }\end{array}$ & $\begin{array}{l}\text { Freedman et al. } \\
\text { (2015) }\end{array}$ \\
\hline & ESCs and iPSCs & $\begin{array}{l}\text { PSC-derived intermediate } \\
\text { mesoderm was treated } \\
\text { with GSK-3b inhibitor and } \\
\text { FGF9 to differentiate into } \\
\text { nephron progenitor cells of } \\
\text { metanephric mesenchyme } \\
\text { and to further induce } \\
\text { pretubular aggregates and } \\
\text { renal vesicles }\end{array}$ & $\begin{array}{l}\text { Contains epithelial } \\
\text { nephron-like structures } \\
\text { expressing markers of } \\
\text { podocytes, proximal } \\
\text { tubules, loops of Henle, } \\
\text { and distal tubules in an } \\
\text { organized, continuous } \\
\text { arrangement }\end{array}$ & gentamicin and cisplatin & $\begin{array}{l}\text { Expression of kidney } \\
\text { injury biomarker (Kim-1) }\end{array}$ & $\begin{array}{l}\text { Morizane et al. } \\
\text { (2015) }\end{array}$ \\
\hline & iPSCs & $\begin{array}{l}\text { Monolayer culture of PSC- } \\
\text { derived posterior primitive } \\
\text { streak to induce } \\
\text { intermediate mesoderm, } \\
\text { followed by a 3D culture to } \\
\text { promote self-organizing } \\
\text { nephrogenic events } \\
\text { leading to organoid } \\
\text { formation }\end{array}$ & $\begin{array}{l}\text { Contains nephrons } \\
\text { associated with a collecting } \\
\text { duct network surrounded } \\
\text { by renal interstitium and } \\
\text { endothelial cells }\end{array}$ & cisplatin & Apoptosis (caspase-3) & $\begin{array}{l}\text { Takasato et al. } \\
\text { (2015) }\end{array}$ \\
\hline & $\begin{array}{l}\text { Renal fibroblasts, } \\
\text { huvec, and } \\
\text { RPTECs }\end{array}$ & $\begin{array}{l}\text { Renal fibroblasts and } \\
\text { huvec were combined in a } \\
50: 50 \text { ratio and seeded } \\
\text { into a microwell plate using } \\
\text { a 3D bioprinter, followed by } \\
\text { the addition of RPTECs }\end{array}$ & $\begin{array}{l}\text { Shows formation of } \\
\text { extensive microvascular } \\
\text { networks and tight } \\
\text { junctions and expression of } \\
\text { renal uptake and efflux } \\
\text { transporters }\end{array}$ & cisplatin & $\begin{array}{l}\text { Viability (LDH release) and } \\
\text { expression of genes } \\
\text { related to fibrosis (TGF } \\
\text { beta) }\end{array}$ & King et al., 2017 \\
\hline $\begin{array}{l}\text { Intestinal } \\
\text { organoid }\end{array}$ & $\begin{array}{l}\text { lleal small intestinal } \\
\text { tissue }\end{array}$ & $\begin{array}{l}\text { Digested human primary } \\
\text { ileal tissue, isolated } \\
\text { intestinal crypts by passing } \\
\text { the minced tissue sections } \\
\text { through filter mesh, and } \\
\text { suspended in Matrigel and }\end{array}$ & $\begin{array}{l}\text { Enteroids collected with a } \\
\text { mean diameter of } 600 \mu \mathrm{m} \\
\text { indicate the presence of } \\
\text { Paneth cells, } \\
\text { enteroendocrine cells, } \\
\text { goblet cells, and } \\
\text { enterocytes }\end{array}$ & $\begin{array}{l}31 \text { marketed } \\
\text { diarrheagenic and non- } \\
\text { diarrheagenic drugs }\end{array}$ & Viability (ATP) & $\begin{array}{l}\text { Belair et al. } \\
(2020)\end{array}$ \\
\hline
\end{tabular}


TABLE 1 | (Continued) Organoid-based toxicity assessment.

\begin{tabular}{|c|c|c|c|c|c|c|}
\hline $\begin{array}{l}\text { Organoid } \\
\text { type }\end{array}$ & $\begin{array}{l}\text { Organoid } \\
\text { sources }\end{array}$ & Fabrication methods & Characteristics & Test substances & Toxic endpoints & References \\
\hline & & $\begin{array}{l}\text { cultured in a specialized } \\
\text { medium }\end{array}$ & & & & \\
\hline & $\begin{array}{l}\text { fibroblasts and } \\
\text { primary small } \\
\text { intestinal epithelial } \\
\text { cells }\end{array}$ & $\begin{array}{l}\text { Generated by seeding } \\
\text { small intestinal epithelial } \\
\text { cells on a supportive layer } \\
\text { of fibroblasts under air- } \\
\text { liquid interface conditions } \\
\text { in a transwell format }\end{array}$ & $\begin{array}{l}\text { Composed of a monolayer } \\
\text { of simple columnar } \\
\text { epithelial cells with basally } \\
\text { positioned nuclei, } \\
\text { consistent with enterocytes }\end{array}$ & $\begin{array}{l}39 \text { marketed drugs with } \\
\text { different diarrhea-genic } \\
\text { risk }\end{array}$ & $\begin{array}{l}\text { Barrier function and Cell } \\
\text { proliferation (MTT assay) }\end{array}$ & $\begin{array}{l}\text { Peters et al. } \\
(2019)\end{array}$ \\
\hline \multirow[t]{4}{*}{$\begin{array}{l}\text { Brain } \\
\text { organoid }\end{array}$} & iPSCs & $\begin{array}{l}\text { Cultured embryoid bodies } \\
\text { generated from iPSC were } \\
\text { embedded in Matrigel and } \\
\text { seeded onto plates in } \\
\text { organoid differentiation } \\
\text { media to form cerebral } \\
\text { organoids and then } \\
\text { transferred to a spinner } \\
\text { platform for long-term } \\
\text { culture }\end{array}$ & $\begin{array}{l}\text { Exhibits similar } \\
\text { developmental. Patterns } \\
\text { and contains multiple types } \\
\text { of brain cells (NSCs, } \\
\text { neurons, and astrocytes), } \\
\text { and distinct multi-layered, } \\
\text { cortical-like neuronal zone } \\
\text { and choroid plexus }\end{array}$ & Ethanol & $\begin{array}{l}\text { Caspase } 3 \text { activity and } \\
\text { functional and } \\
\text { morphological alterations } \\
\text { of mitochondria }\end{array}$ & $\begin{array}{l}\text { Arzua et al. } \\
(2020)\end{array}$ \\
\hline & ESCs & $\begin{array}{l}\text { ESC-derived cerebral } \\
\text { organoids generated by } \\
\text { adding dual SMAD- } \\
\text { signaling inhibitors to } \\
\text { neural induction medium to } \\
\text { promote neuroepithelial } \\
\text { expansion and recapitulate } \\
\text { fetal cerebral development } \\
\text { in vitro }\end{array}$ & $\begin{array}{l}\text { Displays the features of } \\
\text { brain development, } \\
\text { including the expression of } \\
\text { neural stem cells, neurons, } \\
\text { and astrocyte markers, } \\
\text { indicating cerebral } \\
\text { organoid stages up to early } \\
\text { fetal stage }\end{array}$ & acrylamide & $\begin{array}{l}\text { Apoptosis, expression of } \\
\text { genes related to the NRF2 } \\
\text { pathway, and tau } \\
\text { phosphorylation }\end{array}$ & Bu et al. (2020) \\
\hline & iPSCs & $\begin{array}{l}\text { Embryoid bodies } \\
\text { differentiated from iPSC } \\
\text { were cultured in a selected } \\
\text { growth factors and ECM } \\
\text { culture conditions to } \\
\text { generate neuroectoderm, } \\
\text { followed by development } \\
\text { into neural epithelial tissue, } \\
\text { then plated and incubated } \\
\text { on an orbital shaker to form } \\
\text { cerebral organoids }\end{array}$ & $\begin{array}{l}\text { Exhibits complex } \\
\text { morphology and neuron- } \\
\text { specific cell differentiation } \\
\text { and expresses marker } \\
\text { genes related to forebrain, } \\
\text { hippocampus, hindbrain, } \\
\text { and prefrontal cortex }\end{array}$ & vincristine & Caspase 3 activity & Liu et al. (2019) \\
\hline & iPSCs & $\begin{array}{l}\text { Neural progenitor cells } \\
\text { differentiated from iPSC } \\
\text { were differentiated into } \\
\text { brainspheres by incubating } \\
\text { in a dedicated } \\
\text { differentiation medium } \\
\text { under constant gyratory } \\
\text { shaking for up to } 8 \text { weeks }\end{array}$ & $\begin{array}{l}\text { Expresses mature neuronal } \\
\text { markers (NF200, } \beta \text { III- } \\
\text { tubulin and MAP2), } \\
\text { astrocytic marker GFAP, } \\
\text { and oligodendrocyte } \\
\text { marker O1, indicating that } \\
\text { diverse neuronal and glial } \\
\text { cell populations are present }\end{array}$ & rotenone & $\begin{array}{l}\text { Reactive oxygen species } \\
\text { (ROS) and mitochondrial } \\
\text { function }\end{array}$ & $\begin{array}{l}\text { Pamies et al. } \\
(2018)\end{array}$ \\
\hline
\end{tabular}

organoids from hESCs. They added acrylamide (ACR), which is a common food contaminant that has been reported to have neurotoxic effects in preclinical studies, to organoids to understand the mechanisms of ACR-induced neurotoxicity in human brain development (Bu et al., 2020). The results revealed significantly increased nuclear factor erythroid 2-related factor 2 (NRF2)-mediated gene expression, induction of cell apoptosis, repression of neuronal differentiation, and promotion of tau hyperphosphorylation following ACR exposure to brain organoids. Liu et al. examined the utility of human cerebral organoids for toxicity assessment using vincristine (a microtubule-destabilizing drug for cancer treatment) to understand the mechanisms of neurotoxicity or developmental neurotoxicity (Liu et al., 2019). They created organoids from human iPSCs using an approach similar to that used by Lancaster et al. (2013). After $48 \mathrm{~h}$ of treatment with vincristine, dose-dependent neurotoxicity and the inhibition of fibronectin and tubulin development were observed in the cerebral organoid (Liu et al., 2019). Pamies et al. proposed the utility of a human iPSC-derived 3D brain model for understanding drug-induced neurotoxicity and developmental neurotoxicity. The fabricated 3D models comprised differentiated mature neurons and glial cells (astrocytes and oligodendrocytes) to recapitulate neuronal-glial interactions 
(Pamies et al., 2018). They examined the effect of acute (24 h or $48 \mathrm{~h}$ ) exposure to rotenone (a natural pesticide and inhibitor of complex I) using a 3D brain model and found that the toxicity of rotenone varied depending on the differentiation status of the cells, showing higher reactive oxygen species (ROS) and higher mitochondrial dysfunction during the early (2 weeks) rather than the later differentiation stages ( 4 or 8 weeks). Interestingly, dopaminergic-neuron selective toxicity was observed at low (non-cytotoxic) concentrations, while astrocytes and other neuronal cell types were affected at high (cytotoxic) concentrations. These reports suggest that $3 \mathrm{D}$ brain organids/ models can be used to assess the toxicity of drugs and help us to gain a better understanding of the mechanisms responsible for toxicity.

\section{Limitations and Future Perspectives}

There are some limitations inherent to 3D brain organoids, such as the absence of microglia and vasculature. To address some of these limitations, Cakir et al. designed hESCs to ectopically expressed human ETS mutant 2 (ETV2) and generated human cortical organoids (hCO) (Cakir et al., 2019). ETV2-expressing cells in hCO contributed to the formation of a complex vascularlike network in the hCO. Interestingly, the presence of vascularlike structures led to enhanced functional maturation of organoids. Several blood-brain barrier characteristics were also observed, including tight junctions, nutrient transporters, and increased expression of transendothelial electrical resistance. Such vascularized organoids will more faithfully recapitulate physiological functions and provide a valuable platform to better understand the mechanisms of brain development and disease, as well as to conduct drug screening in vitro. In addition, in the above-mentioned reports on human brain organoids, only a single drug or substance has been tested in a toxicity validation studies, and many drugs still need to be evaluated. To conduct safety screening in the early stages of drug discovery, whether the predictive accuracy of $3 \mathrm{D}$ organoid-based assays is superior to conventional 2D cultured assays should be urgently examined using a wide variety of currently marketed drugs. In addition, as described in previous sections, since the preparation of $3 \mathrm{D}$ brain organoids requires multiple steps and a significant investment of time, attention should be paid to the reproducibility of results among studies based on organoids, as well as to the assay throughput.

\section{REFERENCES}

Adler, M., Ramm, S., Hafner, M., Muhlich, J. L., Gottwald, E. M., Weber, E., et al. (2016). A Quantitative Approach to Screen for Nephrotoxic Compounds In Vitro. Jasn 27, 1015-1028. doi:10.1681/ASN.2015010060

Ahmed, R. E., Anzai, T., Chanthra, N., and Uosaki, H. (2020). A Brief Review of Current Maturation Methods for Human Induced Pluripotent Stem CellsDerived Cardiomyocytes. Front. Cel Dev. Biol. 8, 178. doi:10.3389/fcell.2020.00178

Almeqdadi, M., Mana, M. D., Roper, J., and Yilmaz, Ö. H. (2019). Gut Organoids: Mini-Tissues in Culture to Study Intestinal Physiology and Disease. Am. J. Physiology-Cell Physiol. 317, C405-C419. doi:10.1152/ajpcell.00300.2017

\section{CONCLUDING REMARKS}

In this review, we summarized the latest information on human organoids from a toxicological perspective and discussed their usefulness, limitations, and prospects, focusing on possible in vitro predictive assays for major organ toxicities (liver, heart, kidney, gut, and brain) that are caused by marketed drugs. There is currently no standardized method for predicting drug-induced organ toxicities using human organoids, and the number of reports describing toxicity studies using human organoids is still very limited. However, as organoid research has shown remarkable progress in the past 10 years and the number of studies on human organoids has increased, more studies are expected in the future to show the potential usefulness of organoids for toxicity evaluations. Furthermore, the combination of $3 \mathrm{D}$ organoid cultures and genome editing (Clevers, 2016), organs-on-a-chip technique ( $\mathrm{Yu}$ et al., 2019) and further attempts to promote the maturation of organoids will help more accurately model human genetic diseases and create more physiologically relevant in vitro models of human organs. These efforts will allow for a better understanding of disease mechanisms, to perform highly predictive assays for drug-induced toxicity, and select better drug candidates during development.

\section{AUTHOR CONTRIBUTIONS}

TM conceived and wrote the entire manuscript under the advice of TS. TS is a corresponding author and reviewed and revised the manuscript. All authors read and approved the final manuscript.

\section{FUNDING}

This work was supported by Takeda Pharmaceutical Company Limited.

\section{ACKNOWLEDGMENTS}

We thank Dr. Hisashi Anayama for supporting this work.

Ando, H., Yoshinaga, T., Yamamoto, W., Asakura, K., Uda, T., Taniguchi, T., et al. (2017). A New Paradigm for Drug-Induced Torsadogenic Risk Assessment Using Human iPS Cell-Derived Cardiomyocytes. J. Pharmacol. Toxicol. Methods 84, 111-127. doi:10.1016/j.vascn.2016.12.003

Archer, C. R., Sargeant, R., Basak, J., Pilling, J., Barnes, J. R., and Pointon, A. (2018). Characterization and Validation of a Human 3D Cardiac Microtissue for the Assessment of Changes in Cardiac Pathology. Sci. Rep. 8, 10160. doi:10.1038/ s41598-018-28393-y

Arzua, T., Yan, Y., Jiang, C., Logan, S., Allison, R. L., Wells, C., et al. (2020). Modeling Alcohol-Induced Neurotoxicity Using Human Induced Pluripotent Stem Cell-Derived Three-Dimensional Cerebral Organoids. Transl. Psychiatry 10, 347. doi:10.1038/s41398-020-01029-4 
Bartfeld, S., and Clevers, H. (2017). Stem Cell-Derived Organoids and Their Application for Medical Research and Patient Treatment. J. Mol. Med. 95, 729-738. doi:10.1007/s00109-017-1531-7

Baxter, M., Withey, S., Harrison, S., Segeritz, C.-P., Zhang, F., Atkinson-Dell, R., et al. (2015). Phenotypic and Functional Analyses Show Stem Cell-Derived Hepatocyte-like Cells Better Mimic Fetal rather Than Adult Hepatocytes. J. Hepatol. 62, 581-589. doi:10.1016/j.jhep.2014.10.016

Behravesh, S., Shomali, N., Danbaran, G. R., Aslani, S., Hemmatzadeh, M., Hosseinzadeh, R., et al. (2020). Cardiotoxicity of Immune Checkpoint Inhibitors: An Updated Review. Biotechnol. Appl. Biochem. doi:10.1002/bab.2081

Bein, A., Shin, W., Jalili-Firoozinezhad, S., Park, M. H., Sontheimer-Phelps, A., Tovaglieri, A., et al. (2018). Microfluidic Organ-On-A-Chip Models of Human Intestine. Cell Mol. Gastroenterol. Hepatol. 5, 659-668. doi:10.1016/j.jcmgh.2017.12.010

Belair, D. G., Visconti, R. J., Hong, M., Marella, M., Peters, M. F., Scott, C. W., et al. (2020). Human Ileal Organoid Model Recapitulates Clinical Incidence of Diarrhea Associated with Small Molecule Drugs. Toxicol. Vitro 68, 104928. doi:10.1016/j.tiv.2020.104928

Bergmann, O., Zdunek, S., Felker, A., Salehpour, M., Alkass, K., Bernard, S., et al. (2015). Dynamics of Cell Generation and Turnover in the Human Heart. Cell 161, 1566-1575. doi:10.1016/j.cell.2015.05.026

Bitar, K. N., and Zakhem, E. (2016). Bioengineering the Gut: Future Prospects of Regenerative Medicine. Nat. Rev. Gastroenterol. Hepatol. 13, 543-556. doi:10.1038/nrgastro.2016.124

Bowlby, M., Peri, R., Zhang, H., and Dunlop, J. (2008). hERG (KCNH2 or Kv11.1) K+ Channels: Screening for Cardiac Arrhythmia Risk. Cdm 9, 965-970. doi:10.2174/138920008786485083

Bu, Q., Huang, Y., Li, M., Dai, Y., Fang, X., Chen, K., et al. (2020). Acrylamide Exposure Represses Neuronal Differentiation, Induces Cell Apoptosis and Promotes Tau Hyperphosphorylation in hESC-Derived 3D Cerebral Organoids. Food Chem. Toxicol. 144, 111643. doi:10.1016/j.fct.2020.111643

Cakir, B., Xiang, Y., Tanaka, Y., Kural, M. H., Parent, M., Kang, Y.-J., et al. (2019). Engineering of Human Brain Organoids with a Functional Vascular-like System. Nat. Methods 16, 1169-1175. doi:10.1038/s41592-019-0586-5

Carr, D. F., Ayehunie, S., Davies, A., Duckworth, C. A., French, S., Hall, N., et al. (2017). Towards Better Models and Mechanistic Biomarkers for Drug-Induced Gastrointestinal Injury. Pharmacol. Ther. 172, 181-194. doi:10.1016/ j.pharmthera.2017.01.002

Carrillo-Salinas, F. J., Ngwenyama, N., Anastasiou, M., Kaur, K., and Alcaide, P. (2019). Heart Inflammation. Am. J. Pathol. 189, 1482-1494. doi:10.1016/ j.ajpath.2019.04.009

Chen, C., Soto-Gutierrez, A., Baptista, P. M., and Spee, B. (2018). Biotechnology Challenges to In Vitro Maturation of Hepatic Stem Cells. Gastroenterology 154, 1258-1272. doi:10.1053/j.gastro.2018.01.066

Chhibber, T., Bagchi, S., Lahooti, B., Verma, A., Al-Ahmad, A., Paul, M. K., et al. (2020). CNS Organoids: an Innovative Tool for Neurological Disease Modeling and Drug Neurotoxicity Screening. Drug Discov. Today 25, 456-465. doi:10.1016/j.drudis.2019.11.010

Chu, T. F., Rupnick, M. A., Kerkela, R., Dallabrida, S. M., Zurakowski, D., Nguyen, L., et al. (2007). Cardiotoxicity Associated with Tyrosine Kinase Inhibitor Sunitinib. The Lancet 370, 2011-2019. doi:10.1016/S0140-6736(07)61865-0

Clevers, H. (2016). Modeling Development and Disease with Organoids. Cell 165, 1586-1597. doi:10.1016/j.cell.2016.05.082

Cook, D., Brown, D., Alexander, R., March, R., Morgan, P., Satterthwaite, G., et al. (2014). Lessons Learned from the Fate of AstraZeneca's Drug Pipeline: a FiveDimensional Framework. Nat. Rev. Drug Discov. 13, 419-431. doi:10.1038/nrd4309

Cyganek, L., Tiburcy, M., Sekeres, K., Gerstenberg, K., Bohnenberger, H., Lenz, C., et al. (2018). Deep Phenotyping of Human Induced Pluripotent Stem CellDerived Atrial and Ventricular Cardiomyocytes. JCI Insight 3. doi:10.1172/ jci.insight.99941

Czerniecki, S. M., Cruz, N. M., Harder, J. L., Menon, R., Annis, J., Otto, E. A., et al. (2018). High-Throughput Screening Enhances Kidney Organoid Differentiation from Human Pluripotent Stem Cells and Enables Automated Multidimensional Phenotyping. Cell Stem Cell 22, 929-940. doi:10.1016/j.stem.2018.04.022

Dedhia, P. H., Bertaux-Skeirik, N., Zavros, Y., and Spence, J. R. (2016). Organoid Models of Human Gastrointestinal Development and Disease. Gastroenterology 150, 1098-1112. doi:10.1053/j.gastro.2015.12.042
Den Braver-Sewradj, S. P., den Braver, M. W., Vermeulen, N. P. E., Commandeur, J. N. M., Richert, L., and Vos, J. C. (2016). Inter-donor Variability of Phase I/phase II Metabolism of Three Reference Drugs in Cryopreserved Primary Human Hepatocytes in Suspension and Monolayer. Toxicol. Vitro 33, 71-79. doi:10.1016/j.tiv.2016.02.013

DesRochers, T. M., Suter, L., Roth, A., and Kaplan, D. L. (2013). Bioengineered 3D Human Kidney Tissue, a Platform for the Determination of Nephrotoxicity. PLoS One 8, e59219. doi:10.1371/journal.pone.00592110.1371/ journal.pone.0059219

Elaut, G., Henkens, T., Papeleu, P., Snykers, S., Vinken, M., Vanhaecke, T., et al. (2006). Molecular Mechanisms Underlying the Dedifferentiation Process of Isolated Hepatocytes and Their Cultures. Cdm 7, 629-660. doi:10.2174/ 138920006778017759

Fatehullah, A., Tan, S. H., and Barker, N. (2016). Organoids as an In Vitro Model of Human Development and Disease. Nat. Cel Biol. 18, 246-254. doi:10.1038/ ncb3312

Feric, N. T., Pallotta, I., Singh, R., Bogdanowicz, D. R., Gustilo, M. M., Chaudhary, K. W., et al. (2019). Engineered Cardiac Tissues Generated in the Biowire II: A Platform for Human-Based Drug Discovery. Toxicol. Sci. 172, 89-97. doi:10.1093/toxsci/kfz168

Ferri, N., Siegl, P., Corsini, A., Herrmann, J., Lerman, A., and Benghozi, R. (2013). Drug Attrition during Pre-clinical and Clinical Development: Understanding and Managing Drug-Induced Cardiotoxicity. Pharmacol. Ther. 138, 470-484. doi:10.1016/j.pharmthera.2013.03.005

Fitzpatrick, S. C.DABT, ERT, U.S. Food and Drug Administration (2020). Predictive Toxicology for Regulatory Decisions: Implementing New Approaches at US Food and Drug Administration. Toxicol. Vitro 63, 104659. doi:10.1016/j.tiv.2019.104659

Forsythe, S. D., Devarasetty, M., Shupe, T., Bishop, C., Atala, A., Soker, S., et al. (2018). Environmental Toxin Screening Using Human-Derived 3D Bioengineered Liver and Cardiac Organoids. Front. Public Health 6, 103. doi:10.3389/fpubh.2018.00103

Freedman, B. S., Brooks, C. R., Lam, A. Q., Fu, H., Morizane, R., Agrawal, V., et al. (2015). Modelling Kidney Disease with CRISPR-Mutant Kidney Organoids Derived from Human Pluripotent Epiblast Spheroids. Nat. Commun. 6, 8715. doi:10.1038/ncomms 9715

Gómez-Lechón, M. J., Tolosa, L., Conde, I., and Donato, M. T. (2014). Competency of Different Cell Models to Predict Human Hepatotoxic Drugs. Expert Opin. Drug Metab. Toxicol. 10, 1553-1568. doi:10.1517/17425255.2014.967680

Grimm, F. A., Iwata, Y., Sirenko, O., Bittner, M., and Rusyn, I. (2015). Highcontent Assay Multiplexing for Toxicity Screening in Induced Pluripotent Stem Cell-Derived Cardiomyocytes and Hepatocytes. ASSAY Drug Dev. Tech. 13, 529-546. doi:10.1089/adt.2015.659

Grossmann, J., Maxson, J. M., Whitacre, C. M., Orosz, D. E., Berger, N. A., Fiocchi, C., et al. (1998). New Isolation Technique to Study Apoptosis in Human Intestinal Epithelial Cells. Am. J. Pathol. 153, 53-62. doi:10.1016/S00029440(10)65545-9

Guo, L., Dial, S., Shi, L., Branham, W., Liu, J., Fang, J.-L., et al. (2011). Similarities and Differences in the Expression of Drug-Metabolizing Enzymes between Human Hepatic Cell Lines and Primary Human Hepatocytes. Drug Metab. Dispos. 39, 528-538. doi:10.1124/dmd.110.035873

Hall, P. S., Harshman, L. C., Srinivas, S., and Witteles, R. M. (2013). The Frequency and Severity of Cardiovascular Toxicity from Targeted Therapy in Advanced Renal Cell Carcinoma Patients. JACC: Heart Fail. 1, 72-78. doi:10.1016/ j.jchf.2012.09.001

Harrison, S. P., Baumgarten, S. F., Verma, R., Lunov, O., Dejneka, A., and Sullivan, G. J. (2021). Liver Organoids: Recent Developments, Limitations and Potential. Front. Med. 8, 574047. doi:10.3389/fmed.2021.574047

Hayakawa, T., Kunihiro, T., Dowaki, S., Uno, H., Matsui, E., Uchida, M., et al. (2012). Noninvasive Evaluation of Contractile Behavior of Cardiomyocyte Monolayers Based on Motion Vector Analysis. Tissue Eng. C: Methods 18, 21-32. doi:10.1089/ten.tec.2011.0273

Hoofnagle, J. H., and Björnsson, E. S. (2019). Drug-induced Liver Injury - Types and Phenotypes. N. Engl. J. Med. 381, 264-273. doi:10.1056/NEJMra1816149

Huch, M., Gehart, H., van Boxtel, R., Hamer, K., Blokzijl, F., Verstegen, M. M. A., et al. (2015). Long-term Culture of Genome-Stable Bipotent Stem Cells from Adult Human Liver. Cell 160, 299-312. doi:10.1016/j.cell.2014.11.050 
Kasendra, M., Tovaglieri, A., Sontheimer-Phelps, A., Jalili-Firoozinezhad, S., Bein, A., Chalkiadaki, A., et al. (2018). Development of a Primary Human Small Intestine-On-A-Chip Using Biopsy-Derived Organoids. Sci. Rep. 8, 2871. doi:10.1038/s41598-018-21201-7

Kerkelä, R., Grazette, L., Yacobi, R., Iliescu, C., Patten, R., Beahm, C., et al. (2006). Cardiotoxicity of the Cancer Therapeutic Agent Imatinib Mesylate. Nat. Med. 12, 908-916. doi:10.1038/nm1446

Keung, W., Chan, P. K. W., Backeris, P. C., Lee, E. K., Wong, N., Wong, A. O. T., et al. (2019). Human Cardiac Ventricular-Like Organoid Chambers and Tissue Strips from Pluripotent Stem Cells as a Two-Tiered Assay for Inotropic Responses. Clin. Pharmacol. Ther. 106, 402-414. doi:10.1002/cpt.1385

Kim, J., Koo, B.-K., and Knoblich, J. A. (2020). Human Organoids: Model Systems for Human Biology and Medicine. Nat. Rev. Mol. Cel Biol. 21, 571-584. doi:10.1038/s41580-020-0259-3

King, S. M., Higgins, J. W., Nino, C. R., Smith, T. R., Paffenroth, E. H., Fairbairn, C. E., et al. (2017). 3D Proximal Tubule Tissues Recapitulate Key Aspects of Renal Physiology to Enable Nephrotoxicity Testing. Front. Physiol. 8, 123. doi:10.3389/fphys.2017.00123

Lafuse, W. P., Wozniak, D. J., and Rajaram, M. V. S. (2020). Role of Cardiac Macrophages on Cardiac Inflammation, Fibrosis and Tissue Repair. Cells 10, 51. doi:10.3390/cells10010051

Lamore, S. D., Kamendi, H. W., Scott, C. W., Dragan, Y. P., and Peters, M. F. (2013). Cellular Impedance Assays for Predictive Preclinical Drug Screening of Kinase Inhibitor Cardiovascular Toxicity. Toxicol. Sci. 135, 402-413. doi:10.1093/toxsci/kft167

Lancaster, M. A., Renner, M., Martin, C.-A., Wenzel, D., Bicknell, L. S., Hurles, M. E., et al. (2013). Cerebral Organoids Model Human Brain Development and Microcephaly. Nature 501, 373-379. doi:10.1038/nature12517

Lee, J.-Y., Han, H.-J., Lee, S.-J., Cho, E.-H., Lee, H.-B., Seok, J.-H., et al. (2020). Use of 3D Human Liver Organoids to Predict Drug-Induced Phospholipidosis. Ijms 21, 2982. doi:10.3390/ijms21082982

Li, R. A., Keung, W., Cashman, T. J., Backeris, P. C., Johnson, B. V., Bardot, E. S., et al. (2018). Bioengineering an Electro-Mechanically Functional Miniature Ventricular Heart Chamber from Human Pluripotent Stem Cells. Biomaterials 163, 116-127. doi:10.1016/j.biomaterials.2018.02.024

Liu, F., Huang, J., and Liu, Z. (2019). Vincristine Impairs Microtubules and Causes Neurotoxicity in Cerebral Organoids. Neuroscience 404, 530-540. doi:10.1016/ j.neuroscience.2018.12.047

Lu, H. R., Whittaker, R., Price, J. H., Vega, R., Pfeiffer, E. R., Cerignoli, F., et al. (2015). High Throughput Measurement of $\mathrm{Ca}++$ Dynamics in Human Stem Cell-Derived Cardiomyocytes by Kinetic Image Cytometery: A Cardiac Risk Assessment Characterization Using a Large Panel of Cardioactive and Inactive Compounds. Toxicol. Sci. 148, 503-516. doi:10.1093/toxsci/kfv201

Lu, J., Einhorn, S., Venkatarangan, L., Miller, M., Mann, D. A., Watkins, P. B., et al. (2015). Morphological and Functional Characterization and Assessment of iPSC-Derived Hepatocytes forIn VitroToxicity Testing. Toxicol. Sci. 147, 39-54. doi:10.1093/toxsci/kfv117

Lübberstedt, M., Müller-Vieira, U., Mayer, M., Biemel, K. M., Knöspel, F., Knobeloch, D., et al. (2011). HepaRG Human Hepatic Cell Line Utility as a Surrogate for Primary Human Hepatocytes in Drug Metabolism Assessment In Vitro. J. Pharmacol. Toxicol. Methods 63, 59-68. doi:10.1016/j.vascn.2010.04.013

Markowitz, G. S., Bomback, A. S., and Perazella, M. A. (2015). Drug-induced Glomerular Disease: Direct Cellular Injury. Cjasn 10, 1291-1299. doi:10.2215/ CJN.00860115

Matsui, T., Miyamoto, K., Yamanaka, K., Okai, Y., Kaushik, E. P., Harada, K., et al. (2019). Cell-based Two-Dimensional Morphological Assessment System to Predict Cancer Drug-Induced Cardiotoxicity Using Human Induced Pluripotent Stem Cell-Derived Cardiomyocytes. Toxicol. Appl. Pharmacol. 383, 114761. doi:10.1016/j.taap.2019.114761

McGowan, J. V., Chung, R., Maulik, A., Piotrowska, I., Walker, J. M., and Yellon, D. M. (2017). Anthracycline Chemotherapy and Cardiotoxicity. Cardiovasc. Drugs Ther. 31, 63-75. doi:10.1007/s10557-016-6711-0

Michel, L., Rassaf, T., and Totzeck, M. (2019). Cardiotoxicity from Immune Checkpoint Inhibitors. IJC Heart \& Vasculature 25, 100420. doi:10.1016/ j.ijcha.2019.100420

Mills, R. J., Parker, B. L., Quaife-Ryan, G. A., Voges, H. K., Needham, E. J., Bornot, A., et al. (2019). Drug Screening in Human PSC-Cardiac Organoids Identifies
Pro-proliferative Compounds Acting via the Mevalonate Pathway. Cell Stem Cell 24, 895-907. e6. doi:10.1016/j.stem.2019.03.009

Mills, R. J., Titmarsh, D. M., Koenig, X., Parker, B. L., Ryall, J. G., Quaife-Ryan, G. A., et al. (2017). Functional Screening in Human Cardiac Organoids Reveals a Metabolic Mechanism for Cardiomyocyte Cell Cycle Arrest. Proc. Natl. Acad. Sci. USA 114, E8372-E8381. doi:10.1073/pnas.1707316114

Morizane, R., Lam, A. Q., Freedman, B. S., Kishi, S., Valerius, M. T., and Bonventre, J. V. (2015). Nephron Organoids Derived from Human Pluripotent Stem Cells Model Kidney Development and Injury. Nat. Biotechnol. 33, 1193-1200. doi:10.1038/nbt.3392

Muguruma, K., Nishiyama, A., Kawakami, H., Hashimoto, K., and Sasai, Y. (2015). Self-organization of Polarized Cerebellar Tissue in 3D Culture of Human Pluripotent Stem Cells. Cel Rep. 10, 537-550. doi:10.1016/j.celrep.2014.12.051

Okai, Y., Matsune, K., Yamanaka, K., Matsui, T., Pfeiffer Kaushik, E., Harada, K., et al. (2020). Video-based Assessment of Drug-Induced Effects on Contractile Motion Properties Using Human Induced Pluripotent Stem Cell-Derived Cardiomyocytes. J. Pharmacol. Toxicol. Methods 105, 106893. doi:10.1016/ j.vascn.2020.106893

Olson, H., Betton, G., Robinson, D., Thomas, K., Monro, A., Kolaja, G., et al. (2000). Concordance of the Toxicity of Pharmaceuticals in Humans and in Animals. Regul. Toxicol. Pharmacol. 32, 56-67. doi:10.1006/rtph.2000.1399

Pamies, D., Block, K., Lau, P., Gribaldo, L., Pardo, C. A., Barreras, P., et al. (2018). Rotenone Exerts Developmental Neurotoxicity in a Human Brain Spheroid Model. Toxicol. Appl. Pharmacol. 354, 101-114. doi:10.1016/j.taap.2018.02.003

Paşca, A. M., Sloan, S. A., Clarke, L. E., Tian, Y., Makinson, C. D., Huber, N., et al. (2015). Functional Cortical Neurons and Astrocytes from Human Pluripotent Stem Cells in 3D Culture. Nat. Methods 12, 671-678. doi:10.1038/nmeth.3415

Patel, N. M., and Birla, R. K. (2018). The Bioengineered Cardiac Left Ventricle. ASAIO J. 64, 56-62. doi:10.1097/MAT.0000000000000642

Patel, N. M., Mohamed, M. A., Yazdi, I. K., Tasciotti, E., and Birla, R. K. (2017). The Design and Fabrication of a Three-Dimensional Bioengineered Open Ventricle. J. Biomed. Mater. Res. 105, 2206-2217. doi:10.1002/jbm.b.33742

Pavkovic, M., and Vaidya, V. S. (2016). MicroRNAs and Drug-Induced Kidney Injury. Pharmacol. Ther. 163, 48-57. doi:10.1016/j.pharmthera.2016.03.016

Peters, M. F., Landry, T., Pin, C., Maratea, K., Dick, C., Wagoner, M. P., et al. (2019). Human 3D Gastrointestinal Microtissue Barrier Function as a Predictor of Drug-Induced Diarrhea. Toxicol. Sci. 168, 3-17. doi:10.1093/toxsci/kfy268

Pfeiffer, E. R., Vega, R., McDonough, P. M., Price, J. H., and Whittaker, R. (2016). Specific Prediction of Clinical QT Prolongation by Kinetic Image Cytometry in Human Stem Cell Derived Cardiomyocytes. J. Pharmacol. Toxicol. Methods 81, 263-273. doi:10.1016/j.vascn.2016.04.007

Poulton, E.-J. (2017). Impedance Measurement in Induced Pluripotent Stem CellDerived Cardiomyocytes. Methods Mol. Biol. 1641, 201-209. doi:10.1007/9781-4939-7172-5_11

Puschhof, J., Pleguezuelos-Manzano, C., Martinez-Silgado, A., Akkerman, N., Saftien, A., Boot, C., et al. (2021). Intestinal Organoid Cocultures with Microbes. Nat. Protoc. 16, 4633-4649. doi:10.1038/s41596-021-00589-z

Pusztaszeri, M. P., Genta, R. M., and Cryer, B. L. (2007). Drug-induced Injury in the Gastrointestinal Tract: Clinical and Pathologic Considerations. Nat. Rev. Gastroenterol. Hepatol. 4, 442-453. doi:10.1038/ncpgasthep0896

Qian, X., Nguyen, H. N., Song, M. M., Hadiono, C., Ogden, S. C., Hammack, C., et al. (2016). Brain-region-specific Organoids Using Mini-Bioreactors for Modeling ZIKV Exposure. Cell 165, 1238-1254. doi:10.1016/j.cell.2016.04.032

Qu, Y., Feric, N., Pallotta, I., Singh, R., Sobbi, R., and Vargas, H. M. (2020). Inotropic Assessment in Engineered 3D Cardiac Tissues Using Human Induced Pluripotent Stem Cell-Derived Cardiomyocytes in the BiowireTM II Platform. J. Pharmacol. Toxicol. Methods 105, 106886. doi:10.1016/j.vascn.2020.106886

Reuben, A., Koch, D. G., and Lee, W. M. (2010). Drug-induced Acute Liver Failure: Results of a U.S. Multicenter, Prospective Study. Hepatology 52, 2065-2076. doi:10.1002/hep.23937

Richards, D. J., Coyle, R. C., Tan, Y., Jia, J., Wong, K., Toomer, K., et al. (2017). Inspiration from Heart Development: Biomimetic Development of Functional Human Cardiac Organoids. Biomaterials 142, 112-123. doi:10.1016/ j.biomaterials.2017.07.021

Richards, D. J., Li, Y., Kerr, C. M., Yao, J., Beeson, G. C., Coyle, R. C., et al. (2020). Human Cardiac Organoids for the Modelling of Myocardial Infarction and Drug Cardiotoxicity. Nat. Biomed. Eng. 4, 446-462. doi:10.1038/s41551-020-0539-4 
Roden, D. M. (2016). Predicting drug-induced QT prolongation and torsades de pointes. J. Physiol. 594, 2459-2468. doi:10.1113/JP270526

Rodrigues, P. M., and Banales, J. M. (2021). Applications of Organoids in Regenerative Medicine: a Proof-Of-Concept for Biliary Injury. Nat. Rev. Gastroenterol. Hepatol., 371-372. doi:10.1038/s41575-021-00459-9

Saito, J., Okamura, A., Takeuchi, K., Hanioka, K., Okada, A., and Ohata, T. (2016). High Content Analysis Assay for Prediction of Human Hepatotoxicity in HepaRG and HepG2 Cells. Toxicol. Vitro 33, 63-70. doi:10.1016/ j.tiv.2016.02.019

Sakaguchi, H., Kadoshima, T., Soen, M., Narii, N., Ishida, Y., Ohgushi, M., et al. (2015). Generation of Functional Hippocampal Neurons from Self-Organizing Human Embryonic Stem Cell-Derived Dorsomedial Telencephalic Tissue. Nat. Commun. 6, 8896. doi:10.1038/ncomms9896

Sato, T., Vries, R. G., Snippert, H. J., van de Wetering, M., Barker, N., Stange, D. E., et al. (2009). Single Lgr5 Stem Cells Build Crypt-Villus Structures In Vitro without a Mesenchymal Niche. Nature 459, 262-265. doi:10.1038/nature07935

Scheel, O., Frech, S., Amuzescu, B., Eisfeld, J., Lin, K.-H., and Knott, T. (2014). Action Potential Characterization of Human Induced Pluripotent Stem CellDerived Cardiomyocytes Using Automated Patch-Clamp Technology. ASSAY Drug Dev. Tech. 12, 457-469. doi:10.1089/adt.2014.601

Schulze, M. L., Lemoine, M. D., Fischer, A. W., Scherschel, K., David, R., Riecken, K., et al. (2019). Dissecting hiPSC-CM Pacemaker Function in a Cardiac Organoid Model. Biomaterials 206, 133-145. doi:10.1016/j.biomaterials.2019.03.023

Schwartz, R. E., Fleming, H. E., Khetani, S. R., and Bhatia, S. N. (2014). Pluripotent Stem Cell-Derived Hepatocyte-like Cells. Biotechnol. Adv. 32, 504-513. doi:10.1016/j.biotechadv.2014.01.003

Sgodda, M., Dai, Z., Zweigerdt, R., Sharma, A. D., Ott, M., and Cantz, T. (2017). A Scalable Approach for the Generation of Human Pluripotent Stem Cell-Derived Hepatic Organoids with Sensitive Hepatotoxicity Features. Stem Cell Dev. 26, 1490-1504. doi:10.1089/scd.2017.0023

Sharma, A., Burridge, P. W., McKeithan, W. L., Serrano, R., Shukla, P., Sayed, N., et al. (2017). High-throughput Screening of Tyrosine Kinase Inhibitor Cardiotoxicity with Human Induced Pluripotent Stem Cells. Sci. Transl. Med. 9, eaaf2584. doi:10.1126/scitranslmed.aaf2584

Shinozawa, T., Kimura, M., Cai, Y., Saiki, N., Yoneyama, Y., Ouchi, R., et al. (2021). Highfidelity Drug-Induced Liver Injury Screen Using Human Pluripotent Stem CellDerived Organoids. Gastroenterology 160, 831-846. doi:10.1053/j.gastro.2020.10.002

Shirakawa, T., and Suzuki, I. (2020). Evaluation Methods for Drug-Induced Seizure by Microelectrode Array Recording Using Human iPS Cell-Derived Neurons. Folia Pharmacol. Jpn. 155, 284-288. doi:10.1254/fpj.20028

Sjögren, A.-K., Breitholtz, K., Ahlberg, E., Milton, L., Forsgard, M., Persson, M., et al. (2018). A Novel Multi-Parametric High Content Screening Assay in ciPTEC-OAT1 to Predict Drug-Induced Nephrotoxicity during Drug Discovery. Arch. Toxicol. 92, 3175-3190. doi:10.1007/s00204-018-2284-y

Soo, J. Y.-C., Jansen, J., Masereeuw, R., and Little, M. H. (2018). Advances in Predictive In Vitro Models of Drug-Induced Nephrotoxicity. Nat. Rev. Nephrol. 14, 378-393. doi:10.1038/s41581-018-0003-9

Spence, J. R., Mayhew, C. N., Rankin, S. A., Kuhar, M. F., Vallance, J. E., Tolle, K., et al. (2011). Directed Differentiation of Human Pluripotent Stem Cells into Intestinal Tissue In Vitro. Nature 470, 105-109. doi:10.1038/nature09691

Takahashi, Y., Sato, S., Kurashima, Y., Yamamoto, T., Kurokawa, S., Yuki, Y., et al. (2018). A Refined Culture System for Human Induced Pluripotent Stem CellDerived Intestinal Epithelial Organoids. Stem Cel Rep. 10, 314-328. doi:10.1016/j.stemcr.2017.11.004

Takasato, M., Er, P. X., Chiu, H. S., Maier, B., Baillie, G. J., Ferguson, C., et al. (2015). Kidney Organoids from Human iPS Cells Contain Multiple Lineages and Model Human Nephrogenesis. Nature 526, 564-568. doi:10.1038/nature15695

Takebe, T., Sekine, K., Enomura, M., Koike, H., Kimura, M., Ogaeri, T., et al. (2013). Vascularized and Functional Human Liver from an iPSC-Derived Organ Bud Transplant. Nature 499, 481-484. doi:10.1038/nature12271

Takebe, T., Sekine, K., Kimura, M., Yoshizawa, E., Ayano, S., Koido, M., et al. (2017). Massive and Reproducible Production of Liver Buds Entirely from Human Pluripotent Stem Cells. Cel Rep. 21, 2661-2670. doi:10.1016/ j.celrep.2017.11.005

Tiburcy, M., Hudson, J. E., Balfanz, P., Schlick, S., Meyer, T., Chang Liao, M.-L., et al. (2017). Defined Engineered Human Myocardium with Advanced Maturation for Applications in Heart Failure Modeling and Repair. Circulation 135, 1832-1847. doi:10.1161/CIRCULATIONAHA.116.024145
Tolosa, L., Pinto, S., Donato, M. T., Lahoz, A., Castell, J. V., O'Connor, J. E., et al (2012). Development of a Multiparametric Cell-Based Protocol to Screen and Classify the Hepatotoxicity Potential of Drugs. Toxicol. Sci. 127, 187-198. doi:10.1093/toxsci/kfs083

Trefts, E., Gannon, M., and Wasserman, D. H. (2017). The Liver. Curr. Biol. 27, R1147-R1151. doi:10.1016/j.cub.2017.09.019

Van Norman, G. A. (2019). Limitations of Animal Studies for Predicting Toxicity in Clinical Trials. JACC: Basic Translational Sci. 4, 845-854. doi:10.1016/ j.jacbts.2019.10.008

Van Norman, G. A. (2020). Limitations of Animal Studies for Predicting Toxicity in Clinical Trials. JACC: Basic Translational Sci. 5, 387-397. doi:10.1016/j.jacbts.2020.03.010

Vormann, M. K., Gijzen, L., Hutter, S., Boot, L., Nicolas, A., van den Heuvel, A., et al. (2018). Nephrotoxicity and Kidney Transport Assessment on 3D Perfused Proximal Tubules. AAPS J. 20, 90. doi:10.1208/s12248-018-0248-Z

Vriend, J., Nieskens, T. T. G., Vormann, M. K., van den Berge, B. T., van den Heuvel, A., Russel, F. G. M., et al. (2018). Screening of Drug-Transporter Interactions in a 3D Microfluidic Renal Proximal Tubule on a Chip. AAPS J. 20, 87. doi:10.1208/s12248-018-0247-0

Walker, A. L., Imam, S. Z., and Roberts, R. A. (2018). Drug Discovery and Development: Biomarkers of Neurotoxicity and Neurodegeneration. Exp. Biol. Med. (Maywood) 243, 1037-1045. doi:10.1177/1535370218801309

Wang, N.-N., Dong, J., Deng, Y.-H., Zhu, M.-F., Wen, M., Yao, Z.-J., et al. (2016). ADME Properties Evaluation in Drug Discovery: Prediction of Caco-2 Cell Permeability Using a Combination of NSGA-II and Boosting. J. Chem. Inf. Model. 56, 763-773. doi:10.1021/acs.jcim.5b00642

Weersma, R. K., Zhernakova, A., and Fu, J. (2020). Interaction between Drugs and the Gut Microbiome. Gut 69, 1510-1519. doi:10.1136/gutjnl-2019-320204

Wilmer, M. J., Ng, C. P., Lanz, H. L., Vulto, P., Suter-Dick, L., and Masereeuw, R. (2016). Kidney-on-a-chip Technology for Drug-Induced Nephrotoxicity Screening. Trends Biotechnol. 34, 156-170. doi:10.1016/j.tibtech.2015.11.001

Wilson, M. S., Graham, J. R., and Ball, A. J. (2014). Multiparametric High Content Analysis for Assessment of Neurotoxicity in Differentiated Neuronal Cell Lines and Human Embryonic Stem Cell-Derived Neurons. Neurotoxicology 42, 33-48. doi:10.1016/j.neuro.2014.03.013

Xu, S., Sharma, U. C., Tuttle, C., and Pokharel, S. (2021). Immune Checkpoint Inhibitors: Cardiotoxicity in Pre-clinical Models and Clinical Studies. Front. Cardiovasc. Med. 8, 619650. doi:10.3389/fcvm.2021.619650

Yamazaki, D., Kitaguchi, T., Ishimura, M., Taniguchi, T., Yamanishi, A., Saji, D., et al. (2018). Proarrhythmia Risk Prediction Using Human Induced Pluripotent Stem Cell-Derived Cardiomyocytes. J. Pharmacol. Sci. 136, 249-256. doi:10.1016/ j.jphs.2018.02.005

Yu, F., Hunziker, W., and Choudhury, D. (2019). Engineering Microfluidic OrganoidOn-A-Chip Platforms. Micromachines 10, 165. doi:10.3390/mi10030165

Zhang, W. R, and Parikh, C. R. (2019). Biomarkers of Acute and Chronic Kidney Disease. Annu. Rev. Physiol. 81, 309-333. doi:10.1146/annurev-physiol-020518-114605

Zhao, Y., Rafatian, N., Feric, N. T., Cox, B. J., Aschar-Sobbi, R., Wang, E. Y., et al. (2019). A Platform for Generation of Chamber-specific Cardiac Tissues and Disease Modeling. Cell 176, 913-927. doi:10.1016/j.cell.2018.11.042

Conflict of Interest: Authors TM and TS were employed by the company Takeda Pharmaceutical Company Limited.

The authors declare that this study received funding from Takeda Pharmaceutical Company Limited. The funder was involved in the decision to submit it for publication.

Publisher's Note: All claims expressed in this article are solely those of the authors and do not necessarily represent those of their affiliated organizations, or those of the publisher, the editors and the reviewers. Any product that may be evaluated in this article, or claim that may be made by its manufacturer, is not guaranteed or endorsed by the publisher.

Copyright () 2021 Matsui and Shinozawa. This is an open-access article distributed under the terms of the Creative Commons Attribution License (CC BY). The use, distribution or reproduction in other forums is permitted, provided the original author(s) and the copyright owner(s) are credited and that the original publication in this journal is cited, in accordance with accepted academic practice. No use, distribution or reproduction is permitted which does not comply with these terms. 